\title{
Influence of University Course Experience on Graduate Employability Among Commercial Banks in Kenya
}

\author{
Kevin NABALI ${ }^{1} \quad$ John A. ORODHO ${ }^{2}$ Thaddaeus O. RUGAR ${ }^{3}$ \\ 1.Master of Education Student, School of Education, Department of Educational Management, \\ Policy and Curriculum Studies, Kenyatta University, Kenya \\ 2.Associate Professor, School of Education, Department of Educational Management, \\ Policy and Curriculum Studies, Kenyatta University, Kenya \\ 3.Lecturer, Department of Educational Management, Policy and Curriculum Studies
}

\begin{abstract}
The study sought to establish the influence of university course experience on graduate employability among commercial banks in Kenya. The correlational research design was employed for the study. A sample of 393 graduates was randomly selected from a pool of 33,786 working graduates spread out in 41 commercial banks in Kenya. Data on course experience and employability were collected via modified Course Experience questionnaire, of a reliability level Cronbach $\alpha=0.817$, was analyzed using simple linear regression. The study found that course experience of a graduate during training positively influenced his or her employability in the banking sector in Kenya $(\mathrm{p}<.05)$. The study recommends that universities should aim at providing the best learning experiences to their trainees because this influences their prospects of employability into the banking sector.
\end{abstract}

Keywords: Graduate, course experiences, employability, banking sector, University.

DOI: $10.7176 / \mathrm{JEP} / 11-26-02$

Publication date:September $30^{\text {th }} 2020$

\section{Introduction}

There is little doubt that higher education and employment have much to do with each other. According to (West, 2000), employers recruit graduates, individuals seek to enhance their future careers through higher education, university research can lead to the formation of new industries or destruction of existing ones, and governments investing in higher education on behalf of the public - often wish to see some general economic payback. He contends that although the linkages between the labour market and higher education are strong, they are not straightforward, and the respective rights and obligations of higher education institutions, organization's representing labour market interests and governments have been the subject of contest and debate. In the context of this paper, several questions emerge such as: should higher education explicitly aim to advantage its graduates in the labour market? Can higher education effectively add to marketable skills, as well as to knowledge and, if it can, should it?

The foregoing notwithstanding, this paper contends that one of the core business of higher education is to produce high-level skilled individuals for the labour market. However, in Kenya $49 \%$ of the more than 40,000 graduates annually are not ready for employment (Inter-University Council for East Africa, 2014). Part of the reasons attributed to this statistic are quality challenges in higher education institutions. A British Council sponsored study reported that increased access to university education contributed to less emphasis on quality (McCowan, et al., 2016). Against this backdrop, not much has been done to determine how the course experiences of a graduate during training influences their transition into the labor market and employability upon completion.

\section{The State-of-the-Art Review}

In 2000, a joint World Bank/UNESCO scheme led to the publication of Higher Education in Developing Countries: Perils and Promise. This publication promoted the importance of tertiary education as a production line for skilled labour for poverty reduction, human capital and capacity building. This report also underscored the need to explore the emerging need for accountability at the higher education level in terms of the value gained by graduates from training institutions with respect to their employability (Task Force on Higher Education and Society, 2000).

According to (Yorke, 2004), employability refers to possession set of achievements skills, understandings and personal attributes that makes graduates more likely to gain employment and be successful in their chosen occupations, which benefits themselves, the workforce, the community and the economy. Possession of these special achievement skills would be a determinant of their employability value in terms of their likelihood of acquiring employment within a given period of active job search.

Various researchers have conducted studies on the causes of graduate unemployability. (Naong, 2011) analyzed the reasons contributing to graduate unemployment and found that most graduates will struggle to find employment because they chose the wrong field during training. (Lie, Pang, \& Mansur, 2009) notes that graduates should not be blamed entirely for their inability to get employment since graduates focus on abstract and academic qualifications, therefore they are ignorant of the latest labor market requirements in an ever-changing environment. 
Employers and universities are therefore to blame for not equipping trainees with the latest skills requirements. Other reasons highlighted by research as being causes for graduate unemployment include differentials in the quality of university attended and poor job search practices (Moleke, 2010).

According to the Graduate Careers Council of Australia -GCCA (which adopted course experience graduate surveys from 1993-2015), possession of special graduate talent that is so desired by employers could be traced back to the course experiences and training practices graduates were exposed to during training. These course experiences cut across the perceived quality of actual teaching graduates were exposed to, the learning environment, institutional assessment methods and enhancement of generic skills. The justification of these four or more elements as indicators of course experience, its' strength and limitations have been reviewed leading up to their universal adoption into the Course Experience Questionnaire-CEQ. One of the recent reviews is the work of Joy Talukdar, Tania Aspland and Poulmee- Datta (2013). These authors have provided insights , implications and recommendations for the use of CEQ by the Australian higher education which found that the CEQ data has increasingly become very important in institutional performance evaluation even though with controversies .

The idea of using students' surveys like the CEQ to evaluate programs is still controversial. Since its initial development and use by Paul Ramsden and Paul Entwistle (1981, the questionnaire has undergone various modifications (Ramsden \& Entwistle, 1981),. However, the use of CEQ is still widespread with its validity and reliability found to be high (reliability alpha coefficient of $0.75-0.88$ ) for all existing modified versions. Stuart Palmer and Malcolm Campbell (2012) of Faculty of Science and Built Environment, Deakin University pioneered the use of CEQ. In a research project seeking to validate a 2012 CEQ comment data from a survey done by the faculty, it was established that the course design section of the questionnaire generated the most comments. The research also established that the CEQ generally generated meaningful information finding support for a previously proposed five factor domain structure previously proposed in 2006 (Palmer \& Campbell, 2013). To underscore its use further, the successful of CEQ has prompted the adoption of a similar National Students Survey in the United Kingdom and Ireland.

In Kenya, scholars have underscored quality challenges as being a major issue. A 2011 report - University Expansion in Kenya and Issues of Quality Education: Challenges and Opportunities noted that quality challenges on learning experiences undermined the ability of universities to produce employable graduates (Gudo, Olel, \& Oanda, 2011). Another report commissioned by The British Council International Organization for cultural relations and educational opportunities - Universities, employability and inclusive development notes that many public institutions have very large class sizes, with most of them exceeding 500 students in an undergraduate class. (McCowan, et al., 2016). These quality challenges have translated into dissatisfaction with graduates' skills and their ability to transit to the labour market as only about $45 \%$ of over 40,000 graduates annually are employed, leaving $55 \%$ to suffer the burden of unemployment for the next 3 to 5 years (Inter-University Council for East Africa, 2014). Calls for accountability have gained momentum in Kenya, whose university graduates have been criticized for being less competitive and/or lacking basic traits and skills expected of a graduate. One key area of concern is the training practices in relation to learner experiences during training (Wanzala, 2015).

This paper provides a detailed summary of a study done in 2018 on the influence course experience gained from Kenya's higher education institutions has on the employability of graduates with focus on graduates working into the banking sector in Kenya. The study targeted the banking sector because it is one of the largest employers of skilled labour in the private sector while also being one of the top contributors to long-run economic growth (Kenya Nationa Bureau of Statistics, 2015).

\section{Problem Statement}

It is a forgone conclusion that higher education should prepare an individual for a seamless transition and functioning in the labor market. Despite significant monitoring of university education in Kenya, Kenyan university graduates are increasingly finding it hard to earn and maintain employment with more than half of the 40,000 graduates annually unsuitable for employment. Some stakeholders are reluctant to admit a share of the responsibility for the true extent of Kenya's graduate unemployment, while employers tend to apportion most of the blame to universities vis a vis their training practices. In return, universities stakeholders tend to blame employers for offering limited opportunities for students to prepare themselves for transition to the workplace after completion of their studies. This necessitates the need establish how course experiences and training practices influence employability of graduates with focus on banking sector graduates. This study was set to find out how graduates course experiences during training influenced their employability by time spent between graduation and first employment for workers in the banking sector in Kenya.

\section{Research Methodology}

\subsection{Research Method and Design}

To investigate the relationship between graduate course experience and their employability into the banking sector, a correlational research design was adopted. Correlational design is used when there is need to study a problem 
requiring the identification of the nature and degree of association between to sets of variables (Creswell, 2012). This design was deemed suitable for measuring the study variables (graduate course experience and employability) then assess the correlation between the two variables.

\section{a. Population and Sampling}

The target population for this study were all Kenyan University graduates employed in the banking sector. A 2016 Central Bank of Kenya annual supervision report shows that as of Dec 2016, the banking sector in Kenya had 33,786 graduates working in financial institutions in Kenya. Data shows that 10,310 occupied managerial positions, 6,973 in supervisory positions and 16,503 occupied mid and entry-level positions (Central Bank of Kenya, 2016). From this study population, a sample of 393 graduates was selected randomly. According to (Orodho, 2009), a good sample should contain elements representing all the characteristics found in the whole population. All 393 individuals were graduates from Kenyan universities with a common supervised baseline of training.

\subsection{Instrument}

Data on graduate course experience were collected using a modified 1981 version of Paul Ramsden and Noel Entwistle Course Perceptions Questionnaire - CPQ that they used to assess the college experience of British students in certain under-graduate programs and faculties. The original CPQ had 40 items fragmented into eight scales each reflecting varying aspects of quality teaching (Ramsden \& Entwistle, 1981). In 1991, Ramsden developed a revised Course Experience questionnaire (CEQ) which was used as a performance indicator to monitor and evaluate the quality of teaching among academic programs (Ramsden, 1991). This version had 30 items, namely: 8 items good teaching scale; 5 items on goals and standards scale; 5 items on proper workload scale; 6 items on appropriate assessment scale and 6 items on emphasis on independence.

For this study, an even shorter Course Experience Questionnaire with 18 positively stated items fragmented into 5 scales to be scored in a Likert scale of 1-5 was used. Responds were asked to indicate their agreement or disagreement to each of the items. The five scales were; The Good Teaching scale, Learning Environment Scale, a new scale on Generic Skills, Assessment Scale and Overall Satisfaction Scale. The total score for course experience was 90 while the least score is 18 . This questionnaire generated Graduate Course Experience scores as numerical continuous data in ratio scale. Employability was expressed as time spent in active job search in interval scale.

\subsection{Data Analysis}

Descriptive and Inferential statistics were used in this study. Inferentially, this study used correlation and simple linear regression analysis because it is the main statistical concept of analysis in relationship types of studies (Liu, Bridgeman, \& Adler, 2012). For a quantitative study, correlation expresses in mathematical terms the degree of association between two or more variables (Orodho, Nzabalirwa, Odundo, Ndirangu, \& Ndayambaje, 2016). Correlation coefficients were determined using Pearson's product-moment, which is used for continuous variables (Muijs, McAteer, \& Tolmie, 2011). The findings of the study were presented in tables and Regression plots.

\section{Results and Discussions}

The aim of this study was to establish relationship between Graduate's Course Experience and employability into the banking sector in Kenya. Time spent on job search being a measure of employability, the study found that more than half $(58.8 \%)$ of the graduates were employed within the first 18 months of graduation, as displayed in Table1.

Table 1: Time Spent between graduation and first employment.

\begin{tabular}{lccc}
\hline $\begin{array}{l}\text { Time Spent between graduation and first } \\
\text { employment }\end{array}$ & Frequency (n) & Percent (\%) & $\begin{array}{c}\text { Cumulative Percentage } \\
(\%)\end{array}$ \\
\hline Less than 6 months & 128 & 32.8 & 32.8 \\
7 - 12 months & 64 & 16.0 & 48.9 \\
13 - 18 months 18 & 39 & 9.9 & 58.8 \\
19 - 24 months & 45 & 11.5 & 70.2 \\
25 - 30 months & 28 & 6.9 & 77.1 \\
31 - 36 months & 31 & 9.9 & 87.0 \\
37 - 42 months & 15 & 3.8 & 90.8 \\
Above 42 months & 36 & 9.2 & 100.0 \\
Total & 393 & 100.0 & \\
\hline
\end{tabular}

Total

Average time 18.82 months 393

Source: Researcher's Field data, (2018)

Respondents were further asked to rate their course experiences on the five scales of the graduate course experience assessment tool. The responses were subjected to descriptive statistical analysis and the results were summarized and presented on tables 2 to 6 in the following sections. 
Good Teaching Scale

This scale had five items, namely: teaching staff always focused on high standards of work, teaching staff had clear course objectives before every course, a wide scope of curriculum content, teaching staff were extremely good at explaining concepts and enough contact hours with teaching staff for individualized attention. The ratings of five items is presented on table 2 .

Table 2: Good Teaching Scale

\begin{tabular}{|c|c|c|c|c|c|c|c|c|c|c|c|c|}
\hline & n & $\begin{array}{l}\text { Strongly } \\
\text { Disagree (\%) }\end{array}$ & $\mathbf{n}$ & $\begin{array}{l}\text { Disagree } \\
(\%)\end{array}$ & $\mathbf{N}$ & $\begin{array}{l}\text { Neutral } \\
(\%)\end{array}$ & $\mathbf{N}$ & $\begin{array}{l}\text { Agree } \\
(\%)\end{array}$ & n & $\begin{array}{l}\text { Strongly } \\
\text { Agree (\%) }\end{array}$ & Mean & $\begin{array}{l}\text { Std. } \\
\text { Dev }\end{array}$ \\
\hline $\begin{array}{l}\text { Teaching staff always } \\
\text { focused on high } \\
\text { standards of work. }\end{array}$ & 6 & 1.5 & 39 & 9.9 & 141 & 35.9 & 147 & 37.4 & 60 & 15.3 & 3.55 & 919 \\
\hline $\begin{array}{l}\text { Teaching staff had } \\
\text { clear course objectives. }\end{array}$ & 6 & 1.5 & 33 & 8.4 & 72 & 18.3 & 135 & 34.4 & 147 & 37.4 & 3.98 & 1.016 \\
\hline $\begin{array}{l}\text { There was a Wide } \\
\text { scope of curriculum } \\
\text { content. }\end{array}$ & 51 & 13 & 54 & 13.7 & 141 & 35.9 & 92 & 25.2 & 48 & 12.2 & 3.10 & 1.179 \\
\hline $\begin{array}{l}\text { We had enough contact } \\
\text { hours with teaching } \\
\text { staff. }\end{array}$ & 24 & 6.1 & 75 & 19.1 & 114 & 29.0 & 114 & 29.0 & 66 & 16.8 & 3.31 & 1.141 \\
\hline $\begin{array}{l}\text { Teaching staff were } \\
\text { extremely good at } 3 \\
\text { explaining concepts. }\end{array}$ & & 7.6 & 39 & 9.9 & 156 & 39.7 & 117 & 29.8 & 51 & 13.0 & 3.31 & 1.063 \\
\hline
\end{tabular}

Source: Researcher's Field data, (2018)

Over half $(52.7 \%)$ of respondents agreed that the teaching staff always focused on high standards of work. A clear majority (71.8\%) agreed that the Teaching staff had clear course objectives before every course. However, only $37.4 \%$ felt that there was a wide scope of curriculum content in what they learnt with $35.9 \%$ being unsure. Less than half $(45.8 \%)$ of respondents felt they had enough contact hours with teaching staff giving them individualized attention with faculty members. The high students to staff ratio across most faculties could explain these findings. This is particularly true for three clusters: Education science (1:186), Education Arts (1:66) and Business administration (1:50). (Mukhwana, et al., 2016). Generally, the graduates rated the teaching and learning process fairly with an average score of 3.45 in a scale of 1-5. The total average score for the five elements of the Good Teaching Scale was 17.25 out of a possible 30 .

Learning Environment Scale

This scale had three items, namely: the student class sizes, libraries were well equipped with enough resource materials and strong internet connectivity. The ratings of graduates on these five items is presented on table 3.

Table 3: Learning Environment Scale

\begin{tabular}{|c|c|c|c|c|c|c|c|c|c|c|c|c|}
\hline & $\mathbf{n}$ & $\begin{array}{l}\text { Strongly } \\
\text { Disagree } \\
(\%) \\
\end{array}$ & n & $\begin{array}{l}\text { Disagree } \\
(\%) \\
\end{array}$ & n & $\begin{array}{l}\text { Neutral } \\
(\%)\end{array}$ & $\mathbf{n}$ & $\begin{array}{l}\text { Agree } \\
(\%) \\
\end{array}$ & n & $\begin{array}{l}\text { Strongly } \\
\text { Agree } \\
(\%)\end{array}$ & Mean & $\begin{array}{l}\text { Std. } \\
\text { Dev }\end{array}$ \\
\hline $\begin{array}{l}\text { Class sizes } \\
\text { were }\end{array}$ & 147 & 37.4 & 60 & 15.3 & 75 & 19.1 & 57 & 14.5 & 54 & 13.7 & 2.52 & 1.455 \\
\hline $\begin{array}{l}\text { Manageable. } \\
\text { Library was } \\
\text { well equipped } \\
\text { with latest } \\
\text { resources. }\end{array}$ & 24 & 6.1 & 60 & 15.3 & 111 & 28.2 & 84 & 21.4 & 114 & 29.0 & 3.52 & 1.227 \\
\hline $\begin{array}{l}\text { There was easy } \\
\text { access to } \\
\text { strong internet } \\
\text { connectivity. }\end{array}$ & 42 & 10.7 & 57 & 145.5 & 114 & 29.0 & 99 & 25.2 & 81 & 20.6 & 3.31 & 1.249 \\
\hline
\end{tabular}

Over half (52.7\%) of the respondents felt that the student class sizes were big and not manageable enough. Just about half $(50.4 \%)$ of the respondents agreed that libraries were well equipped with enough resource materials with the latest information. Only (48.8\%) felt that their universities provided strong internet connectivity. These finding agrees with (Okwakol, 2008) who notes that most African universities lacked adequate physical facilities like, libraries, laboratories and lecture rooms and therefore, were unable to offer suitable environment for teaching and learning. Generally, the graduates rated the learning environment moderately with an average score of 3.11 in a scale of 1-5. The total average score for the three elements of the Learning Environment Scale was 9.35 out of a possible 15 .

\section{Generic Skills Scale}

This scale had five items, including enhancement of problem-solving skills, development of ability to work in a team and development of graduate's ability to plan their work. The ratings of graduates on these three items is presented on table 4. 
Table 4: Generic Skills Scale

\begin{tabular}{|c|c|c|c|c|c|c|c|c|c|c|c|c|}
\hline \multirow{5}{*}{$\begin{array}{l}\text { My problem-solving skills were } \\
\text { enhanced by course. } \\
\text { My analytical skills were sharpened by } \\
\text { course. } \\
\text { Course developed my ability to work } \\
\text { as a team member. }\end{array}$} & \multirow[b]{3}{*}{12} & \multirow{2}{*}{$\begin{array}{l}\text { Strongly } \\
\text { Disagre } \\
\%\end{array}$} & \multicolumn{3}{|c|}{ Disagree } & \multirow[t]{2}{*}{$\begin{array}{l}\text { Somewhat } \\
\text { disagree }\end{array}$} & \multirow[b]{2}{*}{$n$} & \multicolumn{2}{|c|}{ Agree } & \multirow{2}{*}{$\begin{array}{l}\text { Strongly } \\
\text { Agree } \\
\% \\
\end{array}$} & \multirow{2}{*}{\multicolumn{2}{|c|}{$\begin{array}{r}\text { MeanStd. } \\
\text { Dev }\end{array}$}} \\
\hline & & & n $\%$ & & n & & & $\%$ & n & & & \\
\hline & & 3.2 & 54 & 13 & 120 & ) & 126 & 632.1 & 81 & U & .53 & 1.059 \\
\hline & 9 & 2 & 57 & 12 & 108 & & 59 & 9 & 60 & & 52 & 992 \\
\hline & 9 & 2.3 & 36 & & 100 & & 38 & 5.1 & 105 & 5 & 3.75 & 1.023 \\
\hline $\begin{array}{l}\text { Course improved my confidence in } \\
\text { tackling unfamiliar problems. }\end{array}$ & 21 & 5 & 3 & 9.5 & 9 & & 00 & 2.7 & 69 & 11 & 3.57 & 1.057 \\
\hline $\begin{array}{l}\text { Course improved my written } \\
\text { communication skills. } \\
\text { Course developed my ability to plan }\end{array}$ & 9 & 2.3 & 75 & 19.1 & 87 & 22.1 & 117 & 729.8 & 105 & 26.7 & 3.60 & 1.139 \\
\hline ny work. & 18 & 4.6 & 30 & 7.6 & 90 & 22.9 & 150 & 38.2 & 105 & 26.7 & 3.75 & 1.074 \\
\hline
\end{tabular}

Most respondents rated the courses they pursued highly in terms of the development of these skills. More than half (52.7\%) agreed that the course they pursued enhanced their problem-solving skills. A clear majority $(61.8 \%)$ were adamant that the course they pursued developed their ability to work as a team member. Similarly, $64.9 \%$ of respondents agreed that the course developed their ability to plan their work. Generally, the graduates rated the contribution of the courses they pursued on enhancement of generic skills rather highly with an average score of 3.62 in a scale of 1-5. The total average score for the six elements of the Generic Skills Scale was 21.72 out of a possible 30 .

Assessment Scale

This scale had three items, namely: appropriate overall assessment, assessment was in line with industry practices and presence or lack of inflation. The ratings of graduates on these three items is presented on table 5 .

Table 5: Assessment Scale

\begin{tabular}{|c|c|c|c|c|c|c|c|c|c|c|c|c|}
\hline & \multicolumn{2}{|c|}{$\begin{array}{l}\text { Strongly } \\
\text { Disagree }\end{array}$} & \multicolumn{3}{|c|}{ Disagree } & \multicolumn{2}{|c|}{ Neutral } & Agree & \multicolumn{2}{|c|}{$\begin{array}{l}\text { Strongly } \\
\text { Agree }\end{array}$} & \multirow{2}{*}{\multicolumn{2}{|c|}{$\begin{array}{r}\text { MeanStd } \\
\text { Dev }\end{array}$}} \\
\hline & $\mathbf{n}$ & $(\%)$ & n & $(\%)$ & $\mathbf{n}$ & $(\%)$ & $\mathbf{n}$ & $(\%)$ & n & $(\%)$ & & \\
\hline $\begin{array}{l}\text { Assessment tested more tha } \\
\text { just rot memory. }\end{array}$ & 33 & 8.4 & 69 & 17.6 & 66 & 16.8 & 78 & 19.8 & 147 & 37.4 & 3.60 & 1.359 \\
\hline $\begin{array}{l}\text { Assessment is/was in line wit } \\
\text { industry practices. } \\
\text { There was never grad }\end{array}$ & 33 & 8.4 & 84 & 21.4 & 123 & 31.1 & 108 & 27.5 & 45 & 11.5 & 3.12 & 1.127 \\
\hline inflation. & 36 & 9.2 & 135 & 34.4 & 87 & 22.1 & 63 & 16.0 & 72 & 18.3 & 3.00 & 1.268 \\
\hline
\end{tabular}

Source: Researcher's Field data, (2018)

More than half (57.2\%) agreed that the overall assessment done by faculties was appropriate enough since it tested more than just rot memory but a wide scope of other skills, they were expected to have acquired by the end of each course taught. However, most of the graduates felt that the assessment was not always in line with industry practices as only $39.0 \%$ felt so. $43.6 \%$ of respondents believed they experienced some inflated grades while less than half (34.3\%) disagreed that there was grade inflation. The average score of assessment scale was found to be 3.24 in a scale of 1-5. The total average score for the three elements of the Assessment Scale was 9.72 out of a possible 15 .

\section{Overall Satisfaction Scale}

The overall satisfaction of banking sector graduates regarding their learning experiences during their undergraduate degree courses is presented on table 6.

Table 6: Overall Satisfaction Scale

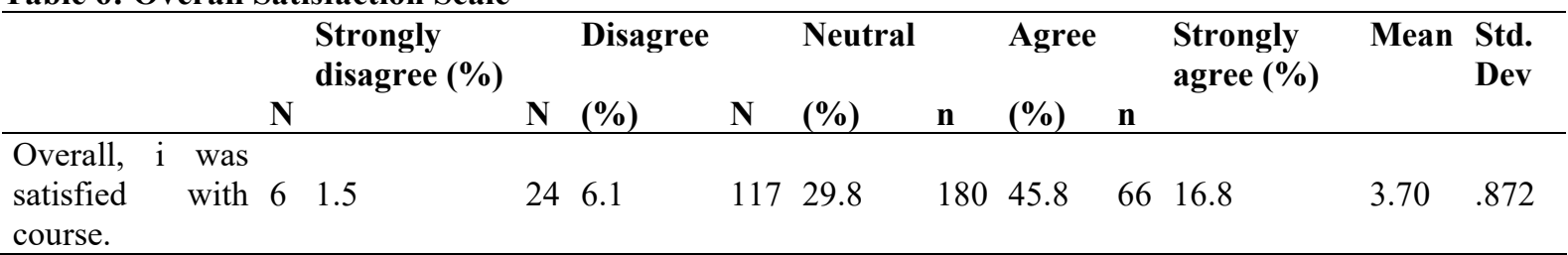

Source: Researcher's Field data, (2018)

Majority $(62.6 \%)$ of the respondents were satisfied with their course experiences at the university they attended. The average score for Overall Satisfaction Scale was 3.70 in a scale of 1-5.

In summary, the respondents rated the learning environment and Assessment models lowest with an average mean score of 3.11 and 3.24 respectively: a clear suggestion that graduates were far from impressed with university assessments and availability of adequate and quality resources to aid in the process of teaching and learning. Class 
Sizes scored lowest of all 18 items with a mean score of 2.52. The poor rating of the learning environment scale and Assessment scale agrees with the findings of (Gudo, Olel, \& Oanda, 2011), from their study: University Expansion in Kenya and Issues of Quality Education: Challenges and Opportunities which found that shortage of lecturers and inefficient management of university examinations are problems affecting both private and public universities in Kenya.

To test the null hypothesis, simple linear regression was performed. The Null hypothesis was:

There is no significant relationship between the Experiences of Graduates during Training at a university and their employability in the banking sector in Kenya.

Firstly, the relationship between the dependent variable (graduate course experience) and the independent variable (employability) was established to show the nature and strength of association between the two. The correlation results are shown on table 7 .

Table 7: Correlation table between Graduate's course Ratings and their employability: $\quad N=393$

Period in months between graduationGraduate Course and employment Experience Ratings -

Period in months betweenPearson Correlation

graduation

employment

Graduate

Experience

$-\mathrm{x} / 90$

**. Correlation is significant at the 0.01 level (2-tailed).

andSig. (2-tailed)

$\mathrm{N}$

CoursePearson Correlation

RatingsSig. (2-tailed)

$\mathrm{N}$

$\mathrm{x} / 90$

$\begin{array}{cc}1 & -.492^{* *} \\ & .000 \\ 393 & 393 \\ -.492^{* *} & 1 \\ .000 & \\ 393 & 393\end{array}$

The table shows that there was a negative and moderate association between graduates' experiences during training and their employability measured by time taken to earn first employment after graduation, at $r=-0.492$, $\mathrm{p}=0.000$.

Respondents who rated their course experiences highly gained employment shortly after graduation. The average course experience rating by all 393 respondents was 61.7328 out of maximum score of 90 . This corresponded to majority of the respondents (58.8\%) reporting to having acquired employment within the first 18 months of graduation.

These findings deviate from the findings of the 2014 IUCEA graduate survey, which noted that at least $55 \%$ of Kenyan graduates suffer the burden of unemployment for the next 3 to 5 years after graduation. The percentage of variance in the dependent variable because of the independent variable was also established.

The percentage of variance in the dependent variable (graduate employability) as a result of the independent variable (graduate course experience) was also established (see Table 8)

Table 8: Model Summary

\begin{tabular}{lr}
\hline Model & Statistic \\
\hline R & $.492^{\mathrm{a}}$ \\
R - Square & .086 \\
Adjusted R - Square & .083 \\
Std. Error of the Estimate & 17.450 \\
\hline
\end{tabular}

a. Predictors: (Constant), Graduate Course Experience Ratings - x/90

b. Dependent Variable: Period in months between graduation and employment

The model revealed that a variation on course experiences accounted for $24.2 \%$ of the variance in the time spent in active job search.

On regressing the two variables, the model results showed that Graduate's course experiences during training had a significant relationship with time spent between graduation and employment, $(p=0.000)$. The null hypothesis was therefore rejected. The regression coefficients is presented in Table 9.

Table 9: Regression Coefficients ${ }^{\mathrm{a}}$

\begin{tabular}{|c|c|c|c|c|c|c|}
\hline Model & & B & Std. Error & Beta & $\mathrm{t}$ & Sig. \\
\hline & (Constant) & 51.557 & 5.485 & & 9.399 & .000 \\
\hline 1 & $\begin{array}{l}\text { Graduate Course } \\
\text { Experience Ratings - x/90 }\end{array}$ & -.530 & .088 & -.492 & -6.047 & .0 \\
\hline
\end{tabular}

a. Dependent Variable: Period in months between graduation and employment

The regression coefficients table 8 shows that the predicted quality of education is equal to $51.557+-.530$.

This means that employability (time taken before first employment) decreased by -0.530 units for each unit of 
increase in graduates course experiences.

The interaction between graduate course experience and graduate employability was presented in a scatter plot shown on Figure 1.

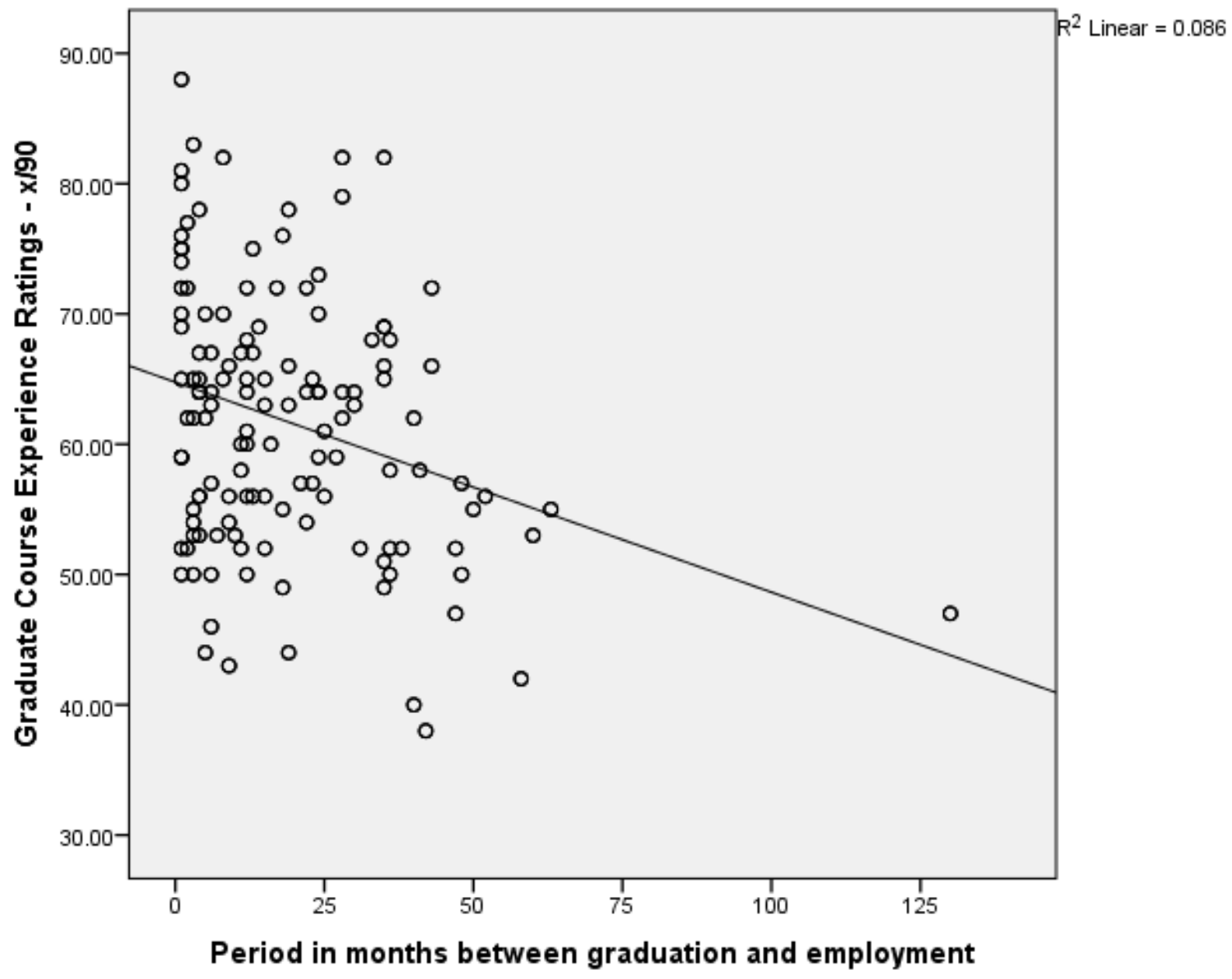

Figure 1: Scatter plot on GCE and period in months between graduation and employment

The trend on the scatter plot shows that an improvement in graduate course experiences, leads to a decrease in the time graduates will spent in active job search. The unmeasured intervening variables have a significant influence on the ability of the predictor variable (graduate course experiences) to predict graduate employability. They include prevailing economic conditions, Socio economic background and Public policies on employment.

This study generated two key findings. Firstly, there is a moderate relationship between graduate course experiences and employability. Graduates' course experiences correlated with their employability at a correlation of -0.492; suggesting that that even though more respondents who rated their course experiences highly gained employment shortly after graduation, the association was a weak one. Graduate course experiences accounted for -0.530 units variation in the time in months graduates will spend in active job search.

Secondly, graduates are impressed with their course experiences with a rating of 61.73 from a maximum score of 90. Only two Course Experience scales had low ratings. i.e the Learning Environment scale and the Assessment Scales with an average mean score of 3.11 and 3.24 respectively on 5-point Likert scale: implying that graduates were not impressed with university assessments models and the availability of adequate and quality resources needed for the process of teaching and learning.

\section{Conclusions and Recommendations}

The following conclusions can be deduced from these key findings. Firstly, given that graduate course experience is an acceptable predictor of employability, it is logical to conclude that extra focus in improving course experiences of students based on the parameters assessed in this study will lead to better graduate outcomes. i.e. more employable graduates. Secondly, even though the graduates rated their course experiences fairly, two aspects of course experience could be better. The aspects of learning experience being the learning environment and the assessment models that were found to be lacking, yet they are critical in aiding better teaching and learning for a graduate with improved employability. 


\section{References}

Central Bank of Kenya. (2016). Bank supervision Annual report. Nairobi: Central Bank of Kenya.

Creswell, J. W. (2012). Educational research: Planning, conducting, and evaluating quantitative and qualitative research (4th ed.). Boston, MA: Pearson.

Gudo, C. O., Olel, M. A., \& Oanda, I. O. (2011). University Expansion in Kenya and Issues of Quality Education: Challenges and Opportunities. International Journal of Business and Social Science.

Inter-University Council for East Africa. (2014). Regional higher education qualifications gaps. Nairobi: InterUniversity Council for East Africa (IUCEA).

Kenya Nationa Bureau of Statistics. (2015). Economic survey, 2015. Nairobi, Kenya: Kenya Nationa Bureau of Statistics.

Kreber, C. (2010). The relationship between students' course perception and their approaches to studying in undergraduate science courses: A Canadian experience. Higher Education Research \& Development, 57-75.

Lie, K. Y., Pang, V., \& Mansur, F. (2009). Employer Perceptions on Graduate Literacies in Higher Education in Relation to the Workplace . Retrieved from http://www.espworld.info/Articles_20/DOC/Koo_vp_employer_Journal18Oct09.pdf

Liu, O. L., Bridgeman, B., \& Adler, R. M. (2012). Measuring Learning Outcomes in Higher Education: Motivation Matters. Educational Researcher, 352-362.

McCowan, T., Walker, M., Fongwa, S., Oanda, I., Sifuna, D., Adedeji, S., . . Tamanja., E. (2016). Universities, employability and inclusive development: repositioning higher education in Ghana, Kenya, Nigeria and South Africa, Universities, employability and inclusive development project. Manchester, England: (British Council), British Co.

Moleke, P. (2010). The graduate labour market: Employment and Economic Policy Research Programme. Cape Town, South Africa: Human Sciences Research Council.

Mugenda, A. G. (2008). Social Science Research: Theory and Principles. Nairobi.: Applied Research \& Training Services.

Muijs, D., McAteer, E., \& Tolmie, A. (2011). Quantitative Methods in Educational and Social Research Using SPSS. London: Open University Press.

Mukhwana, E., Oure, S., Kiptoo, S., Kande, A., Njue, R., Too, J., \& Some., D. (2016). State of University Education in Kenya. Commission for University Education. Discussion Paper 04. . Nairobi, Kenya: Commission for University Education.

Naong, M. N. (2011). Promotion of Entrepreneurship Education - A Remedy to Graduates and Youth Unemployment - A Theoretical Perspective. Journal of Social Sciences, 181-189.

Okwakol, M. (2008). Challenges and Prospects for Quality Assurance in Science and Technology Education in African Countries. Journal of the National Council for Higher Educatio, 17-26.

Orodho, J. A. (2009). Elements of Education and Social Science Research Methods. 2nd Ed. Maseno, Nairobi, Kenya.: Kanezja Publisher.

Orodho, J. A., Nzabalirwa, W., Odundo, P., Ndirangu, W., \& Ndayambaje, I. (2016). Quantitative and Qualitative Research Methods: A step by step guide to scholarly excellence. 1st Ed. Nairobi, Kenya: Kanezja publishers.

Palmer, S., \& Campbell, M. (2013). Practically and productively analysing Course Experience Questionnaire student comment data. Australasian Association for Engineering Education. Conference : (24th : 2013 : Gold Coast, Qld) (p. 9). Brisbane, Qld: Griffith School of Engineering, Griffith University.

Ramsden, P. (1991). A performance indicator of teaching quality in higher education: The course experience questionnaire. Studies in Higher Education, 129-150.

Ramsden, P., \& Entwistle, N. J. (1981). Effects of Academic Departments on Students' Approaches to studying. British Journal of Educatinal psychology, 368-383.

Talukdar, J., Aspland, T., \& Datta, P. (2013). Australian Higher Education and the Course Experience Questionnaire: Insights, Implications and Recommendations. ERIC, p27-35.

Task Force on Higher Education and Society. (2000). Higher education in developing countries : peril and promise. . Washimgton DC: World Bank.

Wanzala, O. (2015, October 1). World Bank raises concern on quality of Kenya's graduates. Retrieved from Daily Nation: $\quad$ https://www.nation.co.ke/news/World-Bank-raises-concern-over-Kenya-s-graduates/10562893556-n01bv0z/index.html

West, J. (2000). Higher education and employment: opportunities and limitations in the formation of skills in a mass of higher education. Journal of Vocational Education and Training, 52:4 573-588.

Yorke, M. (2004). Employabiity in the Undergraduate Curriculum: students' perspectives. European Journal of Education, 409-427. 